\title{
TINDAK PIDANA PERBUATAN CABUL TERHADAP ANAK DI KABUPATEN JENEPONTO
}

\author{
The Obscene Action Crimes Against Children in Jeneponto Regency \\ Sainal $^{1}$, Marwan Mas ${ }^{2}$, Abdul Salam Siku ${ }^{2}$ \\ ${ }^{1}$ Mahasiswa Program Studi Ilmu Hukum Program Pascasarjana Universitas Bosowa \\ ${ }^{2}$ Prodi Ilmu Hukum Universitas Bosowa \\ Email: sainalsh57@gmail.com
}

Diterima: 08 Agustus 2019/Disetujui: 09 Desember 2019

\begin{abstract}
ABSTRAK
Penelitian ini bertujuan untuk mengetahui faktor-faktor yang menyebabkan terjadinya tindak pidana pencabulan terhadap anak di Kabupaten Jeneponto, dan upaya kepolisian untuk mengatasi tindak pidana pencabulan terhadap anak di kabupaten jeneponto. Penelitian ini dilaksanakan di Polres Jeneponto Unit Perlindungan Perempuan dan Anak. Metode penelitian yang digunakan adalah hukum normatif yaitu merupakan penelitian yang mengkaji studi dokumen, yakni menggunakan berbagai bahan hukum primer dan sekunder adapun bahan hukum yang digunakan yaitu bahan hukum primer melalui wawancara langsung kepada narasumber yang berkaitan dengan tulisan ini, dan bahan hukum sekunder denganmengumpulkan data dari berbagi literatur yang ada, berupa buku, artikel-artikel yang diperoleh dari penelusuran internet, termasuk aturanperundangundangan yang terkait dengan permasalahan dalam penelitianini. Hasil penelitian menunjukkan bahwa, (1) faktor-faktor penyebab terjadinya tindak pidana pencabulan terhadap anak yaitu faktor rendahnya Pendidikan dan ekonomi, factor lingkungan atau tempat tinggal, dan faktor teknologi, dan (2) Upaya kepolisian untuk mengatasi tindak pidana pencabulan terjadap anak di kabupaten jeneponto yaitu: Dalam Upaya Preventif pihak kepolisian melakukan beberapa hal yaitu mengadakan penyuluhan hukum dan keagamaan, memberikan arahan kepada masyarakat agar memakai pakaian yang sopan, menciptakan suasana yang tidak menyimpang dengan tata nilai yang dianut oleh masyarakat dan pihak kepolisian rutin melakukan patroli dan razia untuk menanggulangi tindak pidana pencabulan. Sedangkan dalam upaya represif pihak kepolisian melakukan penyelidikan dan penangkapan terhadap tersangka.
\end{abstract}

Kata Kunci: Tindak Pidana, Pencabulan, Kepolisian.

\begin{abstract}
This study aims to determine the factors that led to the crime of sexual abuse of children in Jeneponto Regency, and the police's efforts to deal with crimes against children in Jeneponto Regency. This research was conducted at the Jeneponto Regional Police Unit for the Protection of Women and Children. The research method used is normative law, namely research that examines the study of documents, which uses a variety of primary and secondary legal materials while the legal material used is primary legal material through direct interviews with sources related to this paper, and secondary legal material with collecting data from sharing literature that exists, in the form of books, articles obtained from interne $t$ searches, including laws related to problems in this study. The results showed that, (1) factors that cause the occurrence of criminal acts of sexual abuse against children, namely low education and economic factors, environmental or residential factors, and technological factors, and (2) police efforts to overcome criminal offenses against children in jeneponto district, namely: In Preventive Efforts the police do several things, namely providing legal and religious counseling, giving direction to the public to wear polite clothes, creating an atmosphere that does not deviate from the values adopted by the community and the police regularly conducting patrols and raids to deal with criminal acts of sexual abuse. Whereas in repressive efforts the police conduct investigations and arrests of suspects.
\end{abstract}

Keywords: Crime, Molestation, Police

\section{PENDAHULUAN}

Indonesia merupakan negara yang dibentuk berdasarkan hukum dan telah di gunakan oleh masyarakat dalam kehidupan sehari-hari. Sehingga dalam setiap pergerakan atau perbuatan masyarakat memiliki nilai-nilai hukum di dalamnya. Tetapi, seiring dengan perkembangan zaman jenis-jenis perbuatan yang melanggar hukum yang ada semakin beraneka ragam yang terjadi di dalam masyarakat.

Tindak pidana adalah tindakan yang tidak hanya diru-muskan oleh kitab undang-undang hukum pidana sebagai kejahatan atau tindak pidana. Jika dalam arti luas 
hal ini berhubungan dengan pembahasan masalah delikuens, devi-asi, kualitas kejahatan berubah-ubah, proses kriminalisasi dan deskriminalisasi suatu tindakan atau tindak pidana mengingat tempat, waktu, kepentingan dan kebijaksanaan golongan yang berkuasa dan pandangan hidup, berhubu-ngan dengan perkembangan sosial, ekonomi dan kebuda-yaan pada masa dan tempat tertentu (Arief, 2005;Anonim, 2019).

Tindak pidana pencabulan adalah suatu tindak pidana yang bertentanggan dan melanggar kesopanan dan kesusilaan seseorang yang semuanya dalam lingkungan nafsu birahi kelamin, misalnya seorang laki-laki meraba kelamin seorang perempuan (Alam, 2010; Ali, 2016).

Tindak pidana pencabulan di atur dalam kitab undang-un-dang pidana (KUHP) pada bab XIV Buku keII yakni dimulai dari Pasal 289-296 KUHP, yang selanjutnya dika-tegorikan sebagai kejahatan terhadap kesusilaan. Tindak pidana pencabulan tidak hanya di atur dalam KUHP saja namun di atur pula pada UndangUndang No. 17 Tahun 2016 tentang penetapan Peraturan Pemerintah Penganti Undang-Undang Nomor 1 Tahun 2016 tentang perubahan kedua atas Undang-Undang Nomor 35 Tahun 2014 tentang Perlindungan Anak. Berdasarkan penjelasan tersebut mengenai tindak pidana cabul yaitu suatu tinda-kan yang dilakukan oleh seseorang yang di dorong oleh keinginan seksual untuk melakukan hal-hal yang dapat membangkitkan hawa nafsu birahi, sehingga menim-bulkan kepuasan pada dirinya (Marlina, 2009; Moeljatno, 2009).

Tindak pidana pencabulan itu terus akan berkembang hingga sekarang, dapat dikatakan tidak ada perubahan yang berarti meski struktur dan budaya masyarakat ber-kembang menuju kearah modern. Masalah kejahatan merupakan bagian dari perubahan sosial dan bukan hal yang baru, pada prinsipnya meskipun tempat dan wak-tunya berlainan namun tetap dinilai sama (Marpaung, 2008). Peningkatan kejahatan dari waktu ke waktu tidak dapat dihindari, dikarenakan bentuk perubahan sosial se-bagai pendorongnya. Tindak pidana pencabulan ini tidak hanya terjadi dikota-kota bersar, bahkan terjadi di desa-desa terpencil.

Tindak pidana pencabulan terhadap anak sebagai korbannya merupakan salah satu masalah sosial yang sangat meresahkan masyarakat sehingga perlu di cegah dan di tanggulangi. Oleh karena itu, masalah ini perlu mendapatkan perhatian serius dari semua kalangan masyarakat, terutama kalangan kriminolog dan penegak hukum lainnya (Rachmat, 2015).

Kabupaten Jeneponto adalah kabupaten yang sedang ber-kembang dari segala bidang. Begitu pula perkembangan hukumnya akan selalu berkembang seiring dengan per-kembanggan masyarakat (Mulyana, 2015). Demikian pula permasalahan hukum juga akan ikut berkembang seiring dengan perkembangan permasalahan yang terjadi di ma-syarakat. Salah satunya permasalahan tentang tindak pidana pencabulan di Kabupaten Jeneponto yang mempri-hatinkan (Sholehuddin, 2004;Syamsuddin, 2014).

Berdasarkan latar belakang masalah tersebut di atas, maka penulis ingin melakukan penelitian apa sebenarnya yang menjadi faktor penyebab sehingga terjadinya tindak pidana pencabulan serta upaya penegakan hukum apa yang harus ditempuh dalam menanggulangi tindak pidana pencabulan dengan judul "Tindak Pidana Perbuatan Cabul Terhadap Anak di Kabupaten Jeneponto". Adapun tujuan penelitian ini adalah untuk mengetahui faktor-faktor yang menyebabkan terjadinya tindak pidana pencabulan terhadap anak di Kabupaten Jeneponto; dan untuk mengetahui upaya kepolisian untuk mengatasi tindak pidana pencabulan terhadap anak di Kabupaten Jeneponto.

\section{METODE}

Penelitian ini dilaksanakan di Polres Jeneponto. Metode penelitian yang digunakan adalah hukum normatif yaitu meru-pakan penelitian yang mengkaji studi dokumen, yakni meng-gunakan berbagai bahan hukum primer dan sekunder adapun bahan hukum yang digunakan yaitu bahan hukum primer melalui wawancaralangsung kepada narasumber yang berkaitan dengan tulisan ini, dan bahan hukum sekunder serta dengan mengumpulkan data dari berbagi literatur yang ada, berupa buku, artikel-artikel yang diperoleh dari penelusuran internet, termasuk aturan perundang-undangan yang terkait dengan permasalahan dalam penelitian ini.

\section{HASIL DAN PEMBAHASAN}

\section{Kasus Tindak Pidana Pencabulan di Kabupaten Jeneponto}

Tindak pidana Persetubuhan dan tindak pidana Pencabulan di polres Jeneponto, pada tahun 2016 terdapat 1 tindak pidana persetubuhan dan 11 tindak pidana pencabulan, pada tahun 2017 terdapat 1 tindak pidana persetubuhan dan 10 tindak pidana pencabulan, pada tahun 2018 tidak terdapat tindak pidana persetubuhan dan 6 tindak pidana pencabulan. Pada tahun 2016 sampai 2018 tercatat 2 Tindak pidana Perse-tubuhan dan 27 Tindak Pidana Pencabulan. Selengkapnya dapat dilihat pad Tabel 1.

Tabel 1.

Data Mengenai Tindak Pidana Persetubuhan dan Tindak

Pidana Pencabulan di Polres Jeneponto Tahun 2016-2018

\begin{tabular}{cccc}
\hline No & Tahun & $\begin{array}{c}\text { Tindak Pidana } \\
\text { Persetubuhan }\end{array}$ & $\begin{array}{c}\text { Tindak Pidana } \\
\text { Pencabulan }\end{array}$ \\
\hline 1 & 2016 & 1 & 11 \\
2 & 2017 & 1 & 10 \\
3 & 2018 & - & 6 \\
\hline & Total & 2 & 27
\end{tabular}

Sumber: Polres Jeneponto 2018

Dengan melihat data di atas dimana jumlah tindak pidana persetubuhan yang terjadi dilaporkan kepada pihak yang berwajib jumlahnya cukup banyak dibandingkan kasus pencabulan. Adapun hasil wawancara dengan Uji Mughni Kanit V (PPA) Polres Jeneponto, (Wawancara pada tgl 21 Januari 2019) mengatakan bahwa kurangnya laporan menge-nai tindak pidana pencabulan dipengaruhi oleh faktor-faktor berikut:

a. Pihak korban masih anak-anak sehingga tidak tahu akan berbuat apa

b. Pihak korban mendapat ancaman dari pelaku bila memberitahukan apa yang terjadi pada dirinya kepada orang lain

c. Pihak korban merasa malu

d. Pihak keluarga merasa malu sebab merupakan aib keluarga 
e. Pihak korban dan keluarga takut akan hukuman sosial dari masyarakat setempat.

Berdasarkan Tabel 2 menunjukkan bahwa tindak pidana pencabulan terhadap anak di bawah umur di Kabupaten Jeneponto, para penegak hukum telah menerapkan Undang-Undang No. 17 Tahun 2016 tentang penetapan Peraturan Pemerintah Penganti Undang-Undang Nomor 1 Tahun 2016 tentang perubahan kedua atas UndangUndang Nomor 35 Tahun 2014 tentang Perlindungan Anak.

Tabel 2.

Data Kasus Pencabulan Anak di Polres Jeneponto Tahun 2018

\begin{tabular}{|c|c|c|c|}
\hline No & Tersangka & Pasal Yang Dilanggar & Keterangan \\
\hline 1 & Rahim Dg. Sikki & $\begin{array}{l}\text { Pasal } 82 \text { UU } \\
\text { Perlindungan Anak }\end{array}$ & P21 (Selesai) \\
\hline 2 & Jamal Dg. Tompo & $\begin{array}{l}\text { Pasal } 82 \text { UU } \\
\text { Perlindungan Anak }\end{array}$ & P21 (Selesai) \\
\hline 3 & Ilham & $\begin{array}{l}\text { Pasal } 82 \text { UU } \\
\text { Perlindungan Anak }\end{array}$ & $\begin{array}{l}\text { Dicabut } \\
\text { (Menikahi } \\
\text { Korban) }\end{array}$ \\
\hline 4 & Anto & $\begin{array}{l}\text { Pasal } 82 \text { UU } \\
\text { Perlindungan Anak }\end{array}$ & $\begin{array}{l}\text { Dicabut } \\
\text { (Pembinaan } \\
\text { Orang Tua } \\
\text { dan } \\
\text { Kompensasi) }\end{array}$ \\
\hline 5 & Yusuf & $\begin{array}{l}\text { Pasal } 81 \text { dan } 82 \mathrm{UU} \\
\text { Perlindungan Anak }\end{array}$ & $\begin{array}{l}\text { Kirim } \\
\text { Berkas }\end{array}$ \\
\hline 6 & Rahman & $\begin{array}{l}\text { Pasal } 81 \text { dan } 82 \mathrm{UU} \\
\text { Perlindungan Anak }\end{array}$ & Penyidikan \\
\hline
\end{tabular}

Di dalam kasus pencabulan yang korbannya menimpa seorang anak di bawah umur ini menyangkut tentang hak asasi anak sebagai korbannya yang tidak baik mendapatkan perlakuan dalam hal kekerasan seksual sesuai dengan Undang-Undang No. 17 Tahun 2016 tentang penetapan Peraturan Pemerintah Penganti Undang-Undang Nomor 1 Tahun 2016 tentang perubahan kedua atas UndangUndang Nomor 35 Tahun 2014 tentang Perlindungan Anak, pada Pasal 82 yang menyatakan bahwa:

"Setiap orang yang dengan sengaja melakukan kekerasan atau ancaman kekerasan, memaksa, melakukan tipu muslihat, serangkaian kebohongan, atau membujuk anak untuk melakukan atau membiarkan dilakukan perbuatan cabul, dipidana dengan pidana penjara paling lama 15 (lima belas) tahun dan paling singkat 5 (lima) tahun dan denda paling banyak Rp 5 Miliar)".

Pasal di atas, pada kasus pencabulan terhadap anak di bawah umur khususnya dalam menjerat para pelakunya bukan hanya Pasal 285 KUHP saja, akan tetapi pasal tersebut di atas dapat juga menjadi acuan para penegak hukum untuk menjerat para pelaku yang dimana ancaman pidana bagi para pelakunya lebih berat dibandingkan dalam pasal 285 KUHP atau dengan kata lain undangundang mengenai perlindungan anak tersebut janganlah dikesampingkan akan tetapi dipakai dalam menjerat para pelaku yang menjadikan anak-anak-sebagai objeknya.

\section{Faktor-faktor Penyebab Terjadinya Tindak Pidana Pencabulan di Kabupaten Jeneponto}

Hasil wawancara dengan informan pada (tgl 22 Januari 2019), tentang faktor-faktor penyebab tindak pidana pen- cabulan yang dilakukan di kabupaten jeneponto disajikan pada Tabel 3.

\section{a. Faktor rendahnya pendidikan dan ekonomi}

Menurut Bripka Suparjo Ruslan (wawancara pada tgl 23 Januari 2019), Rendahnya tingkat pendidikan formal dalam diri seseorang dapat menimbulkan dampak terhadap masyarakat dan yang bersangkutan mudah terpengaruh melakukan suatu kejahatan tanpa memikirkan akibat dari perbuatannya. Salah satu delik yang berhubungan karena pelakunya memiliki pendidikan formal yang rendah adalah tindak pidana kesusilaan.

Tabel 3.

Faktor-Faktor Penyebab Terjadinya Tindak Pidana Pencabulan

\begin{tabular}{|c|c|c|c|c|}
\hline No & Informan & $\begin{array}{c}\text { Hasil } \\
\text { Wawancara }\end{array}$ & Tema & Tujuan \\
\hline 1 & $\begin{array}{l}\text { Suparjo } \\
\text { Ruslan } \\
\text { (Banit V } \\
\text { PPA Polres } \\
\text { Jeneponto) }\end{array}$ & $\begin{array}{l}\text { Perkembanga } \\
\mathrm{n} \text { yang } \\
\text { semakin maju } \\
\text { dan } \\
\text { dipengaruhi } \\
\text { oleh } \\
\text { kecangihan } \\
\text { teknologi }\end{array}$ & $\begin{array}{l}\text { Faktor- } \\
\text { Faktor } \\
\text { Penyebab } \\
\text { Tindak } \\
\text { Pidana } \\
\text { Pencabulan }\end{array}$ & $\begin{array}{l}\text { Mengetahui } \\
\text { Faktor- } \\
\text { Faktor } \\
\text { penyebab } \\
\text { tindak } \\
\text { pidana } \\
\text { pencabulan }\end{array}$ \\
\hline 2 & $\begin{array}{l}\text { Ramli } \\
\text { Penyidik } \\
\text { PPA Polres } \\
\text { Jeneponto }\end{array}$ & $\begin{array}{l}\text { Perkembanga } \\
\mathrm{n} \text { yang } \\
\text { semakin maju } \\
\text { dan } \\
\text { dipengaruhi } \\
\text { oleh } \\
\text { kencanggihan } \\
\text { teknologi }\end{array}$ & $\begin{array}{l}\text { Faktor- } \\
\text { Faktor } \\
\text { Penyebab } \\
\text { Tindak } \\
\text { Pidana } \\
\text { Pencabulan }\end{array}$ & $\begin{array}{l}\text { Mengetahui } \\
\text { latar } \\
\text { belakang } \\
\text { yang } \\
\text { menjadi } \\
\text { Faktor- } \\
\text { Faktor } \\
\text { Penyebab } \\
\text { Tindak } \\
\text { Pidana } \\
\text { Pencabulan }\end{array}$ \\
\hline 3 & Yusuf & $\begin{array}{l}\text { Saya sering } \\
\text { menonton } \\
\text { video porno } \\
\text { bersama } \\
\text { teman-teman } \\
\text { di internet } \\
\text { lewat HP } \\
\text { teman }\end{array}$ & $\begin{array}{l}\text { Faktor- } \\
\text { Faktor } \\
\text { Penyebab } \\
\text { Tindak } \\
\text { Pidana } \\
\text { Pencabulan }\end{array}$ & $\begin{array}{l}\text { Mengetahui } \\
\text { Faktor- } \\
\text { Faktor } \\
\text { Penyebab } \\
\text { Tindak } \\
\text { Pidana } \\
\text { Pencabulan }\end{array}$ \\
\hline
\end{tabular}

Pencabulan yang terjadi di Kabupaten Jeneponto. Karena pendidikan yang rendah maka berhubungan dengan taraf ekonomi, dimana ekonomi juga merupakan salah satu penyebab seseorang melakukan suatu perbuatan yang melanggar norma hukum, faktor pendidikan yang rendah dan ekonomi mempengaruhi keadaan jiwa, tingkah laku terutama intelegensinya sehingga mereka dapat melakukan kejahatan dalam hal ini tindak pidana pencabulan pada anak di Kabu-paten Jeneponto.

\section{b. Faktor Lingkungan atau Tempat Tinggal}

Kejahatan asusila adalah merupakan tindak manusia terhadap manusia lainnya di dalam masyarakat. Oleh karena itu, manusia adalah anggota dari masyarakat, maka kejahatan asusila tidak dapat dipisahkan dari masyarakat setempat. Lingkungan sosial tempat hidup seseorang banyak berpe-ngaruh dalam membentuk tingkah laku kriminal, sebab pengaruh sosialisasi seseorang tidak akan lepas dari penga-ruh lingkungan. 
Berdasarkan hasil penelitian ini,bukan hanya pengaruh faktor lingkungan sosial yang ikut berperan akan timbulnya kejehatan tetapi faktor tempat tinggal pun ikut juga mempengaruhi kejahatan seperti tindak pidana asusila terutama tindak pidana Pencabulan, contohnya: Keluarga yang hancur/ broken home tentunya menyebabkan luka batin terhadap anak-anaknya dan kesibukan orang tua dengan pekerjaan menjadikan anak terlantar dan tidak mendapat asuhan dari orang tua dengan maksimal.

\section{c. Faktor Teknologi}

Menurut Ipda Uji Mughni Kanit V Perlindungan Perempuan dan Anak (Wawancara Pada Tgl 22 Januari 2019), Adanya berkembangnya teknologi tentunya membawa pengaruh bagi kehidupan. Pengaruh tersebut meliputi dua sisi yaitu pengaruh positif dan pengaruh negatif. Dampak-dampak pengaruh globalisasi tersebut kita kembalikan kepada diri kita sendiri sebagai generasi muda agar tetap menjaga etika dan budaya, agar kita tidak terkena dampak negatif dari globalisasi. Namun Informasi yang tidak tersaring membuat tidak kreatif, prilaku konsumtif dan membuat sikap menutup diri serta berpikir sempit. Hal tersebut menimbulkan meniru perilaku yang buruk. Mudah terpengaruh oleh hal yang tidak sesuai dengan kebiasaan atau kebudayaan suatu negara yang tidak sesuai dengan norma-norma yang ada .

\section{Upaya Kepolisian Untuk Mengatasi Tindak Pidana Pencabulan di Kabupaten Jeneponto}

\section{a. Upaya preventif}

Upaya preventif adalah upaya pencegahan sebelum terjadinya kejahatan, Dalam upaya preventif yang yang ditekankan adalah menghilangkan kesempatan untuk dilakukannya kejahatan.

\section{1). Individu}

Yang Harus dilakukan oleh setiap individu adalah berusaha untuk terus mencoba agar tidak menjadi korban kejahatannya khususnya pencabulan, salah satunya adalah tidak memberikan kesempatan atau ruang kepada setiap orang atau setiap pelaku untuk melakukan kejahatan. Salah satunya yaitu dengan: Menghindari pakaian yang dapat menimbulkan rangsangan seksual terhadap lawan jenis; dan Tidak tidur bersama dengan anggota keluarga yang berlainan jenis yang telah dewasa.

\section{2). Masyarakat}

Upaya yang dilakukan Polres Jeneponto agar mencegah terjadinya tindak pidana kesusilaan yaitu menciptakan suasana yang tidak menyimpang dengan tata nilai yang dianut oleh masyarakat". Adapun usaha-usaha yang dilakukan oleh masyarakat untuk mencegah yaitu dengan jalan mengadakan acara silaturahi antara anggota masyarakat yang diisi dengan ceramah-ceramah yang dibawakan oleh tokoh masyarakat dilingkungan tempat tinggal.

\section{3). Usaha yang dilakukan oleh pemerintah}

Mengadakan penyuluhan hukum dan penyuluhan keagamaan

\section{4). Kepolisian}

Usaha yang dilakukan polisi Kabupaten Jeneponto dalam upaya penanggulangan tindak pidana pencabulan di antaranya adalah melakukan patrol/razia rutin untuk meningkatkan suasana kamtibmas dalam kehidupan masyarakat, selain itu kepolisian juga secara rutin memberikan penyuluhan hukum terhadap masyarakat dibantu lembaga terkait .

\section{b. Upaya represif.}

Upaya represif dilakukan pada saat telah terjadi kejahatan yang tindakannya berupa penegakan hukum dengan menjatuhkan hukuman. Upaya yang telah dilakukan Polres Jeneponto dalam mewujudkan upaya represif tersebut adalah dengan memberikan perlakuan terhadap pelaku sesuai dengan akibat yang ditimbulkannya.

Tabel 4.

Upaya Pencegahan

\begin{tabular}{|c|c|c|c|c|}
\hline No & Informan & $\begin{array}{c}\text { Hasil } \\
\text { Wawancara }\end{array}$ & Tema & Tujuan \\
\hline 1 & $\begin{array}{l}\text { Uji Mughni } \\
\text { (Kanit V } \\
\text { PPA Polres } \\
\text { Jeneponto) }\end{array}$ & $\begin{array}{l}\text { Terhadap } \\
\text { pencegahan } \\
\text { Polres } \\
\text { Jeneponto } \\
\text { mengadakan } \\
\text { bimbingan dan } \\
\text { Penyuluhan } \\
\text { kepada } \\
\text { masyarakat } \\
\text { khusunya } \\
\text { tentang } \\
\text { pelecehan } \\
\text { seksual dan } \\
\text { diadakannya } \\
\text { pemantauan } \\
\text { dan razia. }\end{array}$ & $\begin{array}{l}\text { Pencegahan } \\
\text { Tindak } \\
\text { Pidana } \\
\text { Pencabulan }\end{array}$ & $\begin{array}{l}\text { Agar } \\
\text { tindak } \\
\text { pidana } \\
\text { pencabul } \\
\text { an dapat } \\
\text { diminim } \\
\text { alisir }\end{array}$ \\
\hline 2 & $\begin{array}{l}\text { Ahmad } \\
\text { (Tokoh } \\
\text { Masyarakat) }\end{array}$ & $\begin{array}{l}\text { Diadakannya } \\
\text { bimbingan dan } \\
\text { peyuluhan } \\
\text { hukum tentang } \\
\text { UU } \\
\text { Perlindungan } \\
\text { Anak dan } \\
\text { pelecahan } \\
\text { seksual serta } \\
\text { penyuluhan } \\
\text { keagamaan }\end{array}$ & $\begin{array}{l}\text { Pencegahan } \\
\text { Tindak } \\
\text { Pidana } \\
\text { Pencabulan }\end{array}$ & $\begin{array}{l}\text { Agar } \\
\text { tindak } \\
\text { pidana } \\
\text { pencabul } \\
\text { an dapat } \\
\text { diminim } \\
\text { alisir }\end{array}$ \\
\hline
\end{tabular}

Sumber : Data Primer yang diolah

\section{KESIMPULAN}

Bahwa faktor-faktor yang menyebabkan terjadinya tindak pidana pencabulan terhadap anak di bawah umur di Jeneponto, yaitu: faktor rendahnya pendidikan dan eko-nomi, faktor lingkungan atau tempat tinggal, faktor minu-man keras, faktor teknologi dan faktor peranan korban; dan dalam upaya Preventif disini adalah upaya-upaya awal yang dilakukan oleh pihak kepolisian untuk mencegah terjadinya tindak pidana. Pihak kepolisian melakukan beberapa hal yaitu mengadakan penyuluhan hukum dan keagamaan, memberikan arahan ke-pada masyarakat agar memakai pakaian yang sopan, men-ciptakan suasana yang tidak menyimpang dengan tata nilai yang dianut oleh masyarakat dan pihak kepolisian rutin me-lakukan patroli dan razia untuk menanggulangi tindak pidana pencabulan. Sedangkan dalam upaya represifmerupakan suatu pengendalian sosial yang dilakukan setelah terjadinya suatu pelanggaran. Atau, merupakan usaha-usaha yang dila-kukan setelah pelanggaran terjadi dalam hal represif pihak kepolisian melakukan penyelidikan dan penangkapan terhadap tersangka.

\section{DAFTAR PUSTAKA}

Alam, A.S. (2010). Pengantar Kriminologi. Pustaka Releksi Books.Makassar. 
Ali, Mahrus. (2016). Dasar-Dasar Hukum Pidana, Penerbit. Sinar Grafika,Jakarta.

Anonim. (2019). Pengertian Alcohol.http://info-narkotika go.id. Diakses diakses pada tanggal 21 Januari 2019 pukul 17:16WITA

Arief, Barda Nawawi. (2005). Bunga Rampai Kebijakan Hukum Pidana, Cet III, Penerbit. PT. CitraBakti. Bandung.

Marlina, (2009), Peradilan Pidana Anak Di Indonesia, Penerbit. PT Refika Aditama. Bandung.

Marpaung, Laden, (2008), Asas-Teori-Praktek Hukum Pidana, Penerbit. Sinar Grafika. Jakarta.

Moeljatno.(2009).Asas-asas Hukum Pidana.Peerbit. PT. Rineka Cipta, Jakarta.

Mulyana W Kusuma, (2015). Perumusan Tindak Pidana Kesusilaan (Perzinaan dan Pemerkosaan) dalam Rancangan KUHP Baru di Tinjau dari Aspek Kebijakan Kriminal dan Aspek Sosial Budaya,Fak. Hukum Universitas Katolik Soegijapranata, Semarang.

Rachmat Harun. (2015). Analisis Yuridis Tentang Tindak Pidana Pencabulan Anak. Lex Crimen Vol. IV/No.4/uni/ 2015.

Sholehuddin, M. (2004). Sistem Sanksi dalam Hukum Pidana, Penerbit. PT. Raja Grafindo,Jakarta.

Syamsuddin, Rahman dan Ismail Aris. (2014). Merajut $\mathrm{Hu}-$ kum di Indonesia. Penerbit. Mitra Wacana Media.Jakarta. 